\title{
Creation of Technical Conditions for Use or Infringement - The Meanders of the Warehouse Keeper's Liability in Light of CJEU Judgment C-567/18 Coty Germany
}

\author{
Krystyna Szczepanowska-Kozłowska $\mathbb{D}$
}

Accepted: 4 February 2021 / Published online: 24 February 2021

(C) The Author(s) 2021

\begin{abstract}
One form of industrial property right infringement is stocking for the purpose of offering or marketing. This form of infringement appears both in EU legal acts on trademarks or designs, as well as in national regulations, including those concerning patents. What is specific to stocking when compared to other activities comprising the stipulated exclusivity of the holder of industrial property rights is the fact that the literal meaning of "stocking" does not explain whether the infringing party or the warehouse keeper is the entity that places the goods in storage. The structure of industrial property rights as absolute rights would theoretically permit the view that the law is violated by both the entity that accepts the goods for storage and the entity that places such goods in storage. To determine if there is an infringement, it must be established what the goods being stocked are further intended for. It is not without significance that the finding of an infringement of industrial property rights does not depend on fault or awareness. From the point of view of the industrial property law regime, it is difficult to find arguments against this understanding of infringement by stocking. Since the offeror of goods infringing industrial property rights may be held liable even if the goods have not yet been manufactured, it is conceivable that the entity accepting such goods for stocking is also liable. This interpretation of the concept of stocking would certainly correspond to the absolute nature of liability for infringement.

In a recent judgment the CJEU confirmed that the warehouse keeper who, on behalf of a third party, stores goods which infringe trademark rights only creates the technical conditions for trademark use by this third party provided that the warehouse keeper is not aware of that infringement. The CJEU also confirmed that only the person who decides about the purpose of storing the goods can be treated as an infringer. However, the CJEU did not respond to the question regarding whether the
\end{abstract}

K. Szczepanowska-Kozłowska $(\bowtie)$

Professor of Law, Department of Intellectual Property and Intangible Goods, Faculty of Law and Administration, Warsaw University, Warsaw, Poland

e-mail: k.szczepanowska_kozlowska@wpia.uw.edu.pl 
warehouse keeper could be treated as an infringer if it pursues the aims of storing the goods at the request of the entity that put the goods into storage.

Keywords Trademarks - Technical conditions for use or infringement - Stocking · Intermediary $\cdot$ Personal pursuit of aims

\section{Stocking as a Form of Infringement Under the Normative Approach}

It seems that stocking, as one of the forms of infringement of exclusive rights, appeared in the European industrial property law along with the Community Patent Convention, which, as we know, has never entered into force. ${ }^{1}$ It was certainly a prototype for national patent regulations, ${ }^{2}$ and with time has been incorporated into legal acts regulating other intangible goods. As D. Stauder accurately pointed out, when commenting on the judgment issued in the UK, which released the entity storing the goods of a third party from the allegation of infringement, ${ }^{3}$ the infringement was extended to the stage of possession of goods, provided that its purpose was to offer, market or use a product embodying a patented solution. ${ }^{4}$ Possession for the purposes of using a patent has, in addition to manufacturing, offering, selling and using, become another independent form of patent infringement. ${ }^{5}$ Even then, attention was drawn to the discrepancies in the individual language versions of the Community Patent Convention, which, however, as emphasized, should not be relevant to the interpretation of this form of patent infringement. While the German version and the French version spoke of possession for the purpose of further activities, the English version used the term "stocking". Therefore, it was emphasized that only then can it be considered that the concept of stocking is not an incorrect translation of this form of patent infringement, if we understand stocking as referring to the person having the right to dispose of the infringing goods. ${ }^{6}$ The reference to possession, therefore, permitted the assumption that it was not the person who merely holds the goods in his/her safekeeping, but the holder who placed the goods in storage and intends to make further use of them by offering and marketing them. Therefore, the use of possession was to resolve any possible doubts as to the entity infringing the patent right. The entity that operates the warehouse and provides storage services is not the holder of goods, but only their keeper.

Therefore, it is not surprising that, following the changes made to the national patent legislation, stocking for the purpose of offering and marketing has also

\footnotetext{
${ }^{1}$ Luxembourg Convention on the Community Patent, signed on 15 December 1979 by nine states, ratified only by seven of the 12 states of the then Community, see Haertel (1986), p. 293; Krieger (1988), p. 143 et seq.

${ }^{2}$ Pila and Torremans (2019), pp. 186-187.

3 High Court of Justice, Patents Court, 7 June 1979, British Airways, IIC 1980, p. 528 et seq.

4 Stauder (1980) in a commentary on the judgment of the High Court of Justice, Patents Court, 7 June 1979, British Airways, IIC 1980, p. 515.

5 Stauder (1980) p. 515.

${ }^{6}$ Stauder (1980), p. 515.
} 
become one of the forms of using a trademark already included in Art. 5(3b) of Directive 89/104. The sphere of exclusivity reserved for the benefit of the proprietor of a trademark right has been defined in the provisions of successive trademark directives which set out a non-exhaustive list of factual acts comprising the socalled use of a trademark reserved solely for the benefit of the proprietor. The exclusivity of the proprietor under Art. 10(2) of current Directive 2015/2436 allows the proprietor to prevent all third parties not having his consent from using the registered sign in the course of trade in relation to goods or services. Article 10(3) of Directive 2015/2436 points to acts that may be prohibited. The enumeration of prohibited acts is only an example, which means that each act of use of a sign in the course of trade, in relation to goods or services, will constitute an encroachment on the sphere of the exclusive right reserved for the proprietor. ${ }^{7}$ Provisions identical to those of Directive 2015/2436 may be found in Art. 9(2) and (3) of Regulation 2017/1001. Both Directive 2015/2436 and Regulation 2017/1001 construe an exclusive right to a registered sign as the right manifesting itself in the ability to prohibit those factual acts by third parties that constitute the use of the sign in the course of trade, indicating merely examples of the forms of such use.

A similar, non-exhaustive list of factual acts that may be prohibited by the design holder may be found in Directive 98/71. According to Art. 12(1) of Directive 98/71, "the aforementioned use shall cover, in particular, the making, offering, putting on the market, importing, exporting or using of a product in which the design is incorporated or to which it is applied, or stocking such a product for those purposes". ${ }^{8}$ It should be pointed out that infringing stocking has also explicitly been extended to those cases where its purpose is import, export or use; hence, all instances of design use.

The wording of the above-mentioned directives and regulations, however, indicates that the individual language versions, as was the case with the Convention on the Community Patent, use different terms to describe what, for example, in Polish law is defined as stocking (sktadowanie) or storage (przechowanie). Certainly, the use of the term of "stocking" in Polish industrial property law is a direct consequence of the adoption, at the time of accession to the EU, of the EU legislation in English as a reference for its Polish-language version. The English version of Directive 2015/2436 (as well as its predecessors) uses the term "stocking". The German version, on the other hand, uses the concept of "possession" ( $z$ u besitzen). Similarly, the French version alludes to possession (déténir). A similar terminological discrepancy is noted under Directive 98/71, where this time the French version uses the term "stockage" corresponding to stocking. This discrepancy in terminology is also reflected in the laws regulating national industrial property rights. The Code de la propriété intellectuelle uses the term "déténtion" in relation to activities reserved for the proprietor of a patent,

\footnotetext{
7 Of course, in a specific situation, it may be necessary to take into account a criterion based on the assessment of infringement of the functions fulfilled by a trademark.

8 An equivalent provision may be found in Art. 19(1) of Council Regulation (EC) 6/2002.
} 
trademark right and design registration right. ${ }^{9}$ Similarly, in German laws we find the term "besitzen". ${ }^{10}$ In turn, in English laws we find a slightly different concept. The 1997 Patent Act in Section 60 states: "keeps it whether for disposal or otherwise". In the Trade Mark Act in Section 10.4 we find a reference to stocking ("it stocks"). The Polish Industrial Property Law Act ${ }^{11}$ consistently uses the term "stocking", sometimes adding "storage", thus referring to the terminology used in the Englishlanguage versions of the referenced documents.

Regardless of whether a specific legal act uses the term "stocking" or the term "possession", this activity, in the light of the existing regulations, must be purposeful. ${ }^{12}$ It is undertaken at least for the purpose of offering or putting goods on the market. Therefore, regardless of the type of the actual power over the thing, as distinguished under private law (possession or keeping as in the case of stocking), it is generally accepted that the mere power over the goods is not sufficient to make an allegation of infringement. This power must be related to the purpose, which is offering or marketing of goods, or - as broadly defined in the English Patent Act also for any other purpose. While the very concept of possession implies the use of the possessed object, "keeping" is the exercise of power for someone else. The type of power exercised, and thus the right to make certain decisions with respect to the goods, arises from the legal relationship that underlies that power. It cannot, therefore, be ruled out that, although we are not dealing with possession for the purpose of offering or marketing, the contract binding on the parties allows the keeper of the goods to undertake certain activities that go beyond those necessary to fulfil the storage obligation.

The existence of directives harmonizing the provisions of the EU Member States and the creation of unitary rights in the EU with regard to trademarks and designs means that the understanding and the construction of individual concepts, including the activities that the proprietor may prohibit third parties from doing, has become the subject of preliminary rulings by the CJEU. The similar construction of the factual activities that make up the sphere of exclusive rights reserved for the proprietor in the case of all industrial property rights makes it possible for the CJEU considerations, to the extent they are not strictly dependent on the construction of a trademark right, to be treated as universal, also for other industrial property rights. Since the issue of liability of the entity storing the goods infringing on industrial property rights in relation to goods infringing on a trademark right has already been the subject of a CJEU decision, one should obviously consider whether the resulting conclusions could also apply to other industrial property rights, which also treat stocking for the purpose of undertaking further activities reserved for the proprietor as an element of a given exclusive right.

\footnotetext{
9 Arts. L713-3-1, L513-4 and L613-3 Code de la propriété intellectuelle, https://www.legifrance.gouv.fr/ affichCode.do?cidTexte=LEGITEXT000006069414, version of 2 August 2020.

10 Sec. 9 German Patent Act; Sec. 14 German Trademark Act; Sec. 38(1) German Design Act.

11 Industrial Property Law Act of 30 June 2000, consolidated text, Journal of Laws of 2020, p. 286.

12 Ingerl and Rohnke (2010), §14, para. 236; Scharen (2015), §9, para. 48; Terrel (2006), para. 8.26.
} 


\section{Stocking as One of the Forms of Trademark Use in Trade}

\subsection{Direct and Indirect Use}

In its judgments, the CJEU has already referred twice to stocking and the possible liability of the entity operating the warehouse for infringing protection rights. ${ }^{13}$ In both judgments, the Court emphasized that the decision on possible liability must answer the question whether the entity storing someone else's goods uses the trademark, thus stressing that the stocking must simultaneously constitute the use of the trademark in order to assign liability for infringement of the trademark right. Therefore, with regard to a trademark right, the starting point must be to answer the question whether the entity in question uses the trademark.

According to the definition proposed by the CJEU, "use involves active behaviour and direct or indirect control of the act constituting the use". ${ }^{14}$ The Court emphasized that the forms of use indicated in the Directive require active behaviour. Such a statement makes it possible to exclude from the concept of use those acts of entities that constitute omission. Additionally, it follows from the above statement that an act may be undertaken directly or indirectly. An indirect act can be understood as a situation where a given entity orders that act to be undertaken by a third party. ${ }^{15}$ While these statements of the Court seem to raise no doubts in general, their confrontation with the actual state on the basis of which they were formulated does raise those doubts. During the term of the agency contract, the agent bought online advertising on the website with the use of the client's trademark. Despite termination of the agency contract, the advertisement for the former agent using a protected trademark continued to be published on that and other websites. After the agency contract ended, the agent requested the websites publishing the advertisement to remove it. Despite a written request from the agent, the advertisement continued to be published. The trademark proprietor filed an infringement lawsuit against the agent. Unfortunately, it is not clear from the facts cited in the decision whether on the date of the proprietor's request the former agent still had a binding contract with the website, or whether that contract was no longer in force at the time of the request, and also whether publication of the advertisement at that time complied with the contract. Those circumstances are not without significance for further evaluation of the Court's judgment.

The judgment emphasizes that the Directive is intended to provide the proprietor with a legal instrument allowing him to prohibit any use of his trademark by a third party without his consent, and thus to stop such unlawful use. The CJEU emphasized that: "However, only a third party who has direct or indirect control of the act constituting the use is effectively able to stop that use and therefore comply with that prohibition". 16 Therefore, we cannot be dealing with use - in a situation

\footnotetext{
${ }^{13}$ CJEU, 16 July 2015, case C-379/14, TOP Logistics BV; CJEU, 2 April 2020, case C-567/18, Coty Germany.

14 CJEU, 3 March 2016, case C-179/15, Daimler, para. 39.

15 The CJEU seems to claim the same, see para. 41 of the judgment in C-179/15, Daimler.

16 CJEU, 3 March 2016, case C-179/15, Daimler, para. 41.
} 
such as in the present judgment - when the activity which the proprietor opposes accrues benefits to a given entity, but that entity is unable to make the third party stop that activity. Ultimately, the CJEU stated that there is no use of someone else's trademark in a situation where that third party expressly requested the entity operating the website, from whom it had ordered an advertisement while still being an agent, to remove the advertisement or the reference to the trademark contained therein. ${ }^{17}$ The aforementioned judgment of the CJEU determines that infringement of a trademark right as well as similar use of other goods protected by industrial property rights is an active behaviour, which seems obvious in the light of the stated forms of trademark use. ${ }^{18}$ On the other hand, assigning liability for that behaviour to a specific entity depends on whether the activity is within its control, in the sense of its ability to stop it. What should be noted in this case, however, is that the Court found that the request to cease was sufficient to conclude that the entity was unable to prohibit the infringing behaviour. Consequently, such an entity cannot be obligated to cease its behaviour.

In the light of that judgment, it seems justified to assume, following the definition of use cited by the CJEU, that use may consist of directing the acts of another person. In this sense, a trademark may be used through another person. This would lead to the conclusion that use may be both a personal act or an act performed on commission. In the latter case, the attribution of use would depend on finding the existence of control over that act, expressed in the ability to stop it. Although the CJEU does not answer the question directly, it should be concluded that in a situation where a third party orders advertising from another entity, then it could be assumed that both that third party and the entity publishing the advertisement use the protected sign. In the case of the principal, this would be indirect use, as he would exercise at least contractual control over the act. In the case of the contractor, the use would be direct. However, in the light of the Court's decision and considerations, this finding may raise questions as to its accuracy.

The CJEU found that, in the circumstances of that situation, the former agent could not prevent the activities of websites. It is clear that in a technical sense such an act on the part of the agent is impossible. However, a question arises whether, in a situation where such an act constitutes improper performance of the contract, assuming that publication of the advertisement violated the contract between the former agent and the website, the act of merely requesting that the act be stopped is a behaviour that should be considered sufficient, and therefore as releasing the former agent from liability. This approach would lead to the absurd conclusion that the party ordering the use of someone else's trademark will not be liable for infringement, as he is not able to prevail upon the entity from which he had ordered that act. Based on the general principles of liability for damages, there is no doubt that the ordering party is liable for the entity it uses. It is impossible to share the CJEU's position that a different decision would violate the impossibilium nulla

\footnotetext{
17 CJEU, 3 March 2016, case C-179/15, Daimler, para. 34.

18 The requirement of active conduct as a prerequisite of infringement is also confirmed in other CJEU judgments, specifically dealing with the place of jurisdiction in case of online infringement: 5 June 2014, case C-360/12, Coty Germany; and CJEU 5 September 2019, case C-172/18, AMS Neve Ltd.
} 
obligatio est principle, and a call to stop publication of an advertisement would exhaust the measures the use of which releases the entity from liability for infringement. ${ }^{19}$ It should also be emphasized that, according to the CJEU's position expressed in this judgment, it cannot be assumed that the proprietor could prohibit, "in a situation such as that at issue in the main proceedings, the disputed use solely on the grounds that such use could possibly bring an economic benefit to the advertiser" ${ }^{20}$ On the one hand, the CJEU expressly states that, in this case, the possible economic benefits on the part of the former agent cannot justify the assumption of an infringement and, consequently, the possibility of ordering that the practice cease. However, the CJEU notes that this does not exclude the possibility of their recovery under national law. ${ }^{21}$ On the other hand, it is impossible not to note that such a statement indicates at least the Court's inconsistency. Since a pecuniary benefit arises on the part of the defendant, there must be an encroachment into the sphere of the claimant's financial interests, which is a characteristic result of an infringement of absolute rights considered in this proprietary approach. After all, the subjective sphere is irrelevant to the assessment of such an infringement. As it seems, it is impossible to derive benefits from the use of a trademark without encroaching on the sphere of stipulated exclusivity, specifically if there is no doubt that the trademark is used in trade as it was in the Daimler case. ${ }^{22}$ Moreover, the Court drew relatively strong attention to the proprietary nature of a trademark right, stressing that only certain forms of use named directly in the Directive, which are not detrimental to the interests of the trademark proprietor, are permissible. ${ }^{23}$ Other forms of use, as long as they are undertaken in the course of trade, will constitute an infringement of a trademark right, if such use may jeopardize any of the trademark functions. In fact, any use of a trademark, unless it is a use permitted by the Directive, will encroach on the sphere of stipulated exclusivity, when it constitutes a breach of the proprietor's legitimate interests expressed in a violation of the functions fulfilled by the trademark. In the context of the CJEU ruling in the Daimler case, the question arises whether the fact that a request to cease and desist is groundless in a given factual situation in the sense that imposing such an obligation on a specific entity will not cause the infringement to end means that the entity does not "use" the trademark, and therefore does not infringe the trademark right. If we interpreted the CJEU judgment in this way, we would have to assume that entrusting activities constituting the use of a trademark relieves the person ordering such activities from liability, transferring that liability merely to the direct contractor, because only he has the technical ability to cease the infringement.

\footnotetext{
19 CJEU, 3 March 2016, case C-179/15, Daimler, para. 42.

20 CJEU, 3 March 2016, case C-179/15, Daimler, para. 45.

21 CJEU, 3 March 2016, case C-179/15, Daimler, para. 43.
}

22 As stated by Advocate General Ruiz-Jarabo Colomer in case C-206/01, Arsenal, para. 62: "The use which the proprietor of the trade mark may prevent is not any that might constitute a material advantage for the user, or even a use which is capable of being expressed in economic terms, but only ... use which occurs in the world of business, in trade, the subject of which is, precisely, the distribution of goods and services in the market".

23 CJEC, 12 November 2002, case C-206/01, Arsenal, para. 54. 


\subsection{Use in the Course of Trade Versus Creation of Technical Conditions for Use}

This, in turn, must lead to the question of whether an entity acting by order of another entity uses a trademark. In answering this question, it is necessary to recall that the use of a trademark must be in the course of trade. This concept appears to have been defined for the first time in the CJEU case law in the Arsenal judgment where the Court emphasized that it is about the use of a sign in the context of a commercial activity aimed at obtaining an economic benefit and not in the private sphere. $^{24}$ This definition was repeated by the CJEU in its subsequent judgments. ${ }^{25}$ A. Kur and M. Senftleben point out that the statement that the use does not take place in the private sphere is not sufficient to establish the existence of an infringement. According to these authors, following the CJEU jurisprudence, it should be assumed that the use encroaching on the sphere protected by exclusive rights occurs when the alleged infringing entity does so in the sphere of its own commercial communication. ${ }^{26}$ These authors, referring to the judgments in Google $^{27}$ and Frisdranken, ${ }^{28}$ stress that the use of a trademark in the course of trade should be distinguished from the creation of technical conditions enabling such use by other persons. The authors' view is well justified by the CJEU case law which emphasizes that the sign must be used in the course of the entity's own commercial activity. The starting point is, of course, the position in the case of Google, which assumes that although an entity such as Google allows the use of protected signs by third parties by storing them as keywords, in the Court's view, it does not use them itself. The fact of creating the technical conditions necessary for the use of a sign and being paid for that service does not mean that the party offering the service itself uses the sign. ${ }^{29}$ In the context of that ruling, it should be emphasized that Google offers the service of using a word constituting a trademark; however, according to the CJEU judgment, only the advertiser uses the mark. Against the background of factual circumstances not related to the internet, it was found that an entity that only filled the cans to which a trademark had been affixed does not use the trademark in its activities. As noted by the Court, there is no link between the bottling service and the trademark placed on the can. As emphasized: "The undertaking which carries out the filling is not apparent to the consumer, which excludes any association between its services and those signs". ${ }^{30}$ The

\footnotetext{
24 Arsenal, para. 40.

25 CJEC, cases C-236/08 to C-238/08 of 23 March 2010, Google France SARL and Google Inc. v. Louis Vuitton Malletier SA (C-236/08), Google France SARL v. Viaticum SA and Luteciel SARL (C-237/08) and Google France SARL v. Centre national de recherche en relations humaines (CNRRH) SARL et al. (C238/08), para. 50; CJEC, 12 November 2002, case C-206/01, Arsenal, para. 40; CJEC, 11 September 2007, case C-17/06, Celine, para. 17; CJEC, 19 February 2009, case C-62/08, UDV North America, para. 44.

26 Kur and Senftleben (2017), p. 276.

27 CJEC, 23 March 2019, cases C-236/08 to 238/08, Google France and Google, para. 50.

28 CJEU, 15 December 2011, case C-119/10, Frisdranken.

29 CJEC, 23 March 2009, cases C-236/08 to C-238/08, Google France and Google, paras. 55-57.

30 CJEU, 15 December 2011, case C-119/10, Frisdranken, para. 33.
} 
participation of the filling service provider can only be considered as allowing another entity to use the signs and not as using them. ${ }^{31}$

Without assessing the view adopted by the CJEU, it is necessary to highlight that these judgments significantly affect the understanding of the concept of use of a trademark by requiring that there be a link between the activity of a given entity and the trademark, consisting in the use of the communicative power of a trademark. The mere use of a sign in the course of trade, even if leading to some income being derived from it, is not yet sufficient to establish that we are dealing with the use of a trademark, and thus an infringement. On the other hand, such use may, according to the CJEU, constitute "creation of technical conditions for use". In particular, in the Google judgment, the Court indicates that such an entity may be an intermediary within the meaning of Arts. 12-15 of Directive 2000/31/EC. ${ }^{32}$ A similar reference can also be found in the Frisdranken judgment ${ }^{33}$ or in the recently issued Coty judgment. ${ }^{34}$ If the analysis were to end with these judgments of the CJEU, it would have to be assumed that "use" of a trademark should be narrowly defined and associated only with the entity using the sign in market communications. Other entities, even if participating in the process of using the sign, can only have the status of so-called "intermediaries" the rules of whose liability under national regimes, apart from the scope of services provided by electronic means and implementation of the provisions of Directive 2000/31, remain imprecisely defined. This fact is not changed by the thesis expressed by the CJEU in the judgment in Tommy Hilfiger ${ }^{35}$ that the conditions for the application of an injunction to be applied to intermediaries in connection with Art. 11, third sentence, of Directive 2004/48 should be identical to those formulated in connection with Directive $2000 / 31$ on the electronic market. Interestingly, in the light of these judgments, it was neither clear nor evident that the entities to whose liability for infringement the CJEU referred also used the sign in market communications and whether, against the background of these facts, any of the entities used the sign in market communications.

However, it cannot be ignored that both the concept of intermediation by creating technical conditions for using a sign, and the concept of using the sign's communicative power, which is to be the criterion for determining whether we are dealing with the use of a trademark, are no longer so clear when the factual acts reserved for the proprietor do not yet permit the conclusion that a given person using the trademark already uses its communicative power. It should be emphasized that this circumstance was also noted by the CJEU. In the TOP Logistic ruling, the Court indicated that the use of a trademark does not always occur in the course of immediate relationships between a trader and a consumer. Therefore, the use of a trademark within the meaning of Art. 10(3) of Directive 2015/2436 cannot be limited to such situations. The use in commercial communications cannot, therefore,

\footnotetext{
31 CJEU, 15 December 2011, case C-119/10, Frisdranken, paras. 34-35.

32 See para. 57 in cases C-236/08 to C-238/08 and the reference therein to para. 107.

33 Para. 35.

34 CJEU, 2 April 2020, case C-567/18, Coty Germany, para. 104.

35 CJEU, 7 July 2016, case C-494/15, Tommy Hilfiger, para. 31.
} 
be regarded as a necessary criterion for establishing that a trademark is being used. If that concept were to be adopted, then stocking of goods could not constitute an infringement of a trademark right. ${ }^{36} \mathrm{We}$ concur with this view of the Court. One can hardly conclude that affixing a sign on a product, which is not yet offered or marketed, is not the use of a trademark due to the lack of use of the sign in market communications. Certainly in a broader context, it can be said that by affixing a sign on goods the proprietor already exercises his exclusive right, but as long as the goods are not offered or marketed, the trademark will not serve as an instrument of commercial communications. It is similar in the case of importation, where the mark also does not have to be used in the importer's own commercial communications.

Since the use of a sign in market communications cannot be a criterion for assessing whether we are dealing with the use of a trademark, it remains to be answered whether a specific act is not merely the creation of a technical possibility of use. This concept has not been defined by the Court. On the basis of the Court's findings to date, it seems right to conclude that such acts are materially outside the sphere of exclusivity arising from the trademark right. This means that the acts which constitute the creation of technical conditions for use cannot correspond to those reserved for the proprietor, as set forth in Art. 10(3) of Directive 2015/2436. This certainly does not fully solve the problem as the enumeration is only exemplary. It becomes difficult, if not impossible, to define the acts enabling use if the use itself remains not fully defined. Referring to the facts in Frisdranken, one concludes that the decision was in fact based on the criterion of trademark use in market communications. Meanwhile, in my view, analysis of the facts shows that we were dealing with affixing a sign on goods rather than with the creation of technical conditions for use of the mark, which is beyond the sphere of exclusivity. It should be taken into account that only the can being filled led to the situation where we obtained trademark-bearing goods. The trademark-bearing can itself was not yet the specific commodity. The act of affixing a sign on goods, reserved for the proprietor, is an act of combining the goods (in this case a beverage) with the trademark which, given the type of goods, can only be affixed on the packaging. Thus, substantively, the act of affixing the sign was carried out by the entity filling the can. Today, this conclusion is additionally supported by Art. 11 of Directive 2015/2436 which clearly indicates that the packaging designated by a trademark may only be evidence of acts preparatory to infringement. The lack of use of a trademark in market communications of the entity filling the can is irrelevant to the assessment of infringement, just as it is irrelevant for any act of affixing a sign on goods. The can filler in this actual situation, acting on the order of another entity, performed the act of affixing the sign on the goods. As in the case of all factual acts reserved for the proprietor, in this case the understanding of this concept must also consider the existing facts. The sequence of individual acts that make up the act of affixing a sign on goods, and the way in which they are performed, is irrelevant to the final outcome which must be combining the goods and the sign.

This concept raises even more doubts against the background of the facts in the Google judgment. What needs to be emphasized is that the facts in the case do not

36 CJEU, 16 July 2015, case C-379/14, TOP Logistics, paras. 40-41. 
concern the use of a trademark in connection with trade in the goods bearing the mark but the use of the created search mechanism based on a keyword that corresponds to the protected sign. Even if we agree with the CJEU's ruling, a legitimate doubt arises whether the conclusions drawn by the Court for that peculiar set of facts involving the use of a mark to create a positioning mechanism for an advertisement could be transposed to facts related to trade in goods. We might as well voice a concern whether the person using the keyword to position advertisements uses it in his market communications, as long as his communications addressed to potential customers do not contain that sign. Moreover, as the CJEU held in the Daimler judgment, the fact of deriving benefits from a given act does not prejudge the use of a trademark. What then, apart from the benefit, would it mean to use a trademark if the user himself does not materialize the protected sign? Leaving detailed assessment of the Google judgment outside the scope of considerations and focusing solely on the concept of creating technical conditions for the use of a sign, as repeated in that judgment, the judgment does not seem to add anything new. It is merely clear that the creation of technical conditions for use is not use within the meaning of Art. 10(2) of the Directive; therefore, a given behaviour materially does not correspond to the features that make up the use.

The CJEU returned to the concept of creating conditions for use when deciding on the liability of the warehouse keeper and, referring to its previous understanding of the concept of use, found that the warehouse keeper does not use the trademark in the course of trade. ${ }^{37}$ The Court ruled that the role of that entity boils down to permitting the use of a trademark by its customers; therefore, it cannot be held liable under Directive 89/104. ${ }^{38}$ In doing so, it referred to its judgment in Frisdranken without elaborating the legal arguments to support its position. More extensive arguments of the CJEU can be found in the Coty judgment. ${ }^{39}$ The judgment confirms the Court's hitherto position that the fact of creating the technical conditions necessary for the use of a trademark and being paid for that service does not mean that the entity creating those conditions itself uses the sign. In this regard, the CJEU referred to its previous case law relating to use. At the same time, there is a new element in the Court's reasoning related to the normative approach to the actual act of stocking. It draws attention to the wording of Art. 9(2)(b) of Regulation 207/2009 (Art. 9(3)(b) of Regulation 2017/1001, respectively), according to which stocking takes place for the purpose of the offering and marketing of goods. ${ }^{40}$ This, in the view of the CJEU, means that in order for the act of stocking to be classified as "using" the sign, it is also necessary for the economic operator providing the stocking itself to pursue the aim which is offering the goods or putting them on the market. ${ }^{41}$ Following the Advocate General, the Court deems in essence that it is the person offering or putting goods on the market who uses the sign since he uses them in his commercial communications. According to further considerations of the

\footnotetext{
37 CJEU, 16 July 2015, case C-379/14, paras. 41-42.

38 CJEU, 16 July 2015, case C-379/14, para. 45.

39 CJEU, 2 April 2020, case C-567/18, Coty Germany.

40 CJEU, 2 April 2020, case C-567/18, Coty Germany, para. 44.

41 CJEU, 2 April 2020, case C-567/18, Coty Germany, para. 45.
} 
Court, for liability to be attributed it is necessary for the person stocking goods to be personally offering or placing them on the market. In the thesis of the ruling, the Court finds in response to the question posed that a person who, on behalf of a third party, stores goods which infringe trademark rights, without being aware of that infringement, must be regarded as not stocking those goods in order to offer them or put them on the market for the purposes of those provisions, if that person does not itself pursue those aims. ${ }^{42}$ It should also be added that the final considerations of the Court also refer to its previous jurisprudence in which it found that allowing a sign to be used by another entity is not covered by Art. 9 of Regulation 207/2009 (or Art. 9 of Regulation 2017/1001, respectively). This time, however, the Court pointed to the provisions that could be the basis for possible liability of such an entity, i.e. Art. 14(1) of Directive 2000/31 or Art. 11, first sentence, of Directive $2004 / 48 .^{43}$

\section{Personal Pursuit of Aims}

Analysis of the Court's judgment in Coty Germany should begin with a reminder that the question was asked by a German court. The question asked, which is not reflected in other language versions, apart from the French version, was in fact aimed at clarifying whether stocking is possession for the purpose of placing on the market if the warehouse keeper does not thereby pursue its own aims. The very way of phrasing the question, it seems, is the consequence of the terminological discrepancies between the various language versions of the directives, as indicated above. Rather, the referring court was trying to decide whether the warehouse keeper could also be treated as the possessor. It seems, however, that this linguistic discrepancy was ultimately irrelevant to the decision of the Court, which did not appear to notice any terminological differences and their possible significance for the decision. Meanwhile, it seems that the question so asked was aimed at clarifying whether the concept of possession in the context of German regulations is the same as in private law. After all, the term "stocking" also has its meaning in private law. It means a certain activity of placing goods. By assumption, stocking is temporary in the sense that it constitutes a certain stage in the turnover of goods. It is characterized by the fact that goods placed in a warehouse (for stocking) have a further destination, e.g. sale, use or destruction. It is obvious that the purpose of stocking goods or their further destination is decided by the entity that can dispose of the goods. In the pure form of a stocking contract, the entity accepting goods for stocking cannot dispose of them; its duty is to store the goods and keep them unchanged. D. Stauder rightly noted that it is not the provision of the service of storing someone else's goods that is an infringement, but only their possession which enables the performance of those acts that constitute the use of an intangible asset underlying a given exclusive right. It, therefore, seems that the Court's intention was rather to decide whether the stocking entity could be treated as the

42 CJEU, 2 April 2020, case C-567/18, Coty Germany, para. 53.
43 CJEU, 2 April 2020, case C-567/18, Coty Germany, para. 50. 
possessor. Looking at the facts of the case, the question asked, and the answer given, a doubt arises whether the issued decision is correct.

In fact, the thesis of the judgment should not come as a surprise whether in the light of previous statements of the Court itself or those of domestic courts. ${ }^{44}$ It is generally believed rather that the entity that only provides the storage service is not the entity held liable for infringement. In the thesis itself, of concern may only be the fact that it includes the condition of being unaware that the goods stored infringe an exclusive right. One cannot resist the impression that the thus formulated thesis leads to an a contrario justified conclusion that an entity that is aware of the infringement should be treated as one that, within the meaning of Art. 9 of the Regulation, stores the goods for the purpose of offering or marketing them. It must not be forgotten that the answer given always reflects the question posed directly by the national court, and that question referred to the warehouse keeper's unawareness of the infringement. It seems, however, that the issue should be addressed by the Court. Infringement of intellectual property rights does not depend on being aware of the infringement, and it is difficult to imagine that awareness of the infringement would have any bearing on whether to consider that the warehouse keeper uses the protected sign. Against the background of facts in the case, both in the question thus worded and in the answer given, one can see a reference to Art. 14 of Directive 2000/31, which makes the service provider's liability for infringement conditional on its being aware of unlawful activities of the entity using its services. The argument thus seems to clearly show that, while the entity that stores the goods infringing intellectual property rights is not liable for infringement, that entity may be held liable as a service provider, as long as it is aware that the goods stored infringe intellectual property rights. However, it should be remembered that the service of stocking goods by its nature cannot be provided electronically. Therefore, this position of the Court can be read as confirmation that the liability of intermediaries in the real world, as in the virtual world, depends on some degree of guilt. Proving guilt of such an entity would open the path for such an entity being held liable for infringement of a trademark right, although the entity does not use the sign. However, the issue of liability of the warehouse keeper as the so-called intermediary within the meaning of Art. 11 of Directive 2004/48 is also quite enigmatic in the light of that judgment. The CJEU refers to the first sentence of Art. 11 of Directive 2004/48, which reads: "Member States shall ensure that, where a judicial decision is taken finding an infringement of an intellectual property right, the judicial authorities may issue against the infringer an injunction aimed at prohibiting the continuation of the infringement". At this point, it should be recalled that Art. 11 of Directive 2004/48 also refers to intermediaries, but only in the third sentence. Analysis of Art. 11 of Directive 2004/48, and especially the third sentence, in combination with the first sentence of that provision, indicates that the first sentence does not refer to intermediaries, but directly to infringers. According to the wording of the third sentence: "Member States shall also ensure that

\footnotetext{
${ }^{44}$ Case C-379/14, para. 45; Decision of German Federal Supreme Court (Bundesgerichtshof), 17 September 2009, case Xa ZR 2/08, MP3 Player, IIC 2010(4), p. 472; Import Smith, Kline \& Laboratories Ltd v. R.D. Harbottle (Mercantile) Ltd [1980] R.P.C. 363, 371-374; McDonald v. Graham [1994] R.P.C. 407, 431.
} 
rightholders are in a position to apply for an injunction against intermediaries whose services are used by a third party to infringe an intellectual property right, without prejudice to Article 8(3) of Directive 2001/29/EC". Such wording indicates that the Member State's obligation to issue injunctions against intermediaries is a separate obligation, in addition to the obligation to take measures against infringers of intellectual property rights. Therefore, the reference to the first sentence might suggest that, after all, it deals with an infringer and not with an intermediary.

Here the question arises whether the activities performed by the defendant in this case can be assessed as stocking, which in itself does not yet lead to an infringement of the exclusive right, and what is meant in this context by the requirement to personally pursue the aim of offering or marketing. In the classic concept of stocking, the warehouse keeper accepts goods for storage and releases them to the depositor or a person designated by him. He does not perform any services other than storage, which involves the obligation of safekeeping the goods. Meanwhile, in many business models, both in online sales and in the ordinary trade in goods, the entity storing the goods may, for example, at the request of the storing entity, repackage the goods, which involves affixing a sign on the goods, or enter into a sales contract or advertise the goods on its behalf, or even enter into a sales contract on behalf of and for the benefit of a third party which in fact remains undisclosed. In a situation where the storekeeper concludes such contracts on his own behalf, it would be obvious that he would remain the entity liable for the infringement by offering and marketing the infringing goods. The question then arises as to how to view the acts undertaken by the warehouse keeper who pursues an aim at the request of the entity that placed the goods in storage.

\section{Infringer or Intermediary}

In essence, the question comes down to a decision whether a person acting for another entity, performing activities which correspond in substance to use of a trademark, is an infringer or merely an intermediary who creates "technical conditions for use of the trade mark". There is also the question of how to treat the party commissioning the activities that meet the definition of using a trademark or using other intangible goods protected by exclusive rights. Moreover, the assessment of the client/service-provider relationship from the point of view of infringement of exclusive rights and possible liability for infringement applies not only to stocking, but also to all forms of use covered by the proprietor's exclusive rights. In the case of stocking, we are dealing with the CJEU's requirement that the entity liable for the infringement by stocking personally pursues the aims of that stocking, that is, offering and marketing.

In the case of the Coty judgment, the CJEU seems to assign liability for infringement only to the person who deposited the goods for the purpose of their storage and sale as the person who personally pursues the aims of offering and marketing. The CJEU does not treat the warehouse keeper as an entity that performs activities other than storage, although the reference to Art. 11, first sentence, of Directive 2004/48 may raise some doubts. This makes it possible to treat this entity 
as one that only creates the technical conditions for use. The issue of possibly acting on the order of the entity that placed the goods in storage, e.g. in terms of offering or marketing, is omitted. On the other hand, in the Daimler case, the CJEU seemed to associate liability for infringement only with the service provider performing the activities in question as the entity that could stop certain acts. In Frisdranken, in turn, that liability appears to be attributed to the party ordering the filling of cans.

It is not easy to assess the relationship between the entity ordering a given activity and the entity performing that activity from the point of view of infringement of industrial property rights, when this activity literally constitutes the use of a trademark. The Polish industrial property law, which does not regulate that situation, is not an exception. ${ }^{45}$ When assessing relationships of two or more entities from the point of view of liability for infringement, reference is usually made to the construction of tort liability for damages. In Polish private law, the liability of two entities for inflicted damage may generally take two forms. The first one concerns the situation where both entities are considered accomplices. There is a relationship required by a given legal regime between the acts of each of the entities. Each of those persons is the direct perpetrator of the damage. In the other situation the perpetrator is one of the entities; the acts of the other entity are not directly related to the perpetrator's deeds but merely constitute aiding and abetting, or inducement to cause damage. Therefore, where acts constituting infringement of an industrial property right are undertaken on the order of another person, the question arises whether both entities should be considered as infringers or whether one of the entities will only be the one that creates technical conditions for use of a trademark or uses another intangible asset, or whether it should be regarded only as the entity inducing an infringing act. As emphasized in writings in the context of general principles of tort liability, it may be difficult to distinguish, especially in the case of aiding and abetting, whether we are dealing with a direct perpetrator or the perpetrator. $^{46}$

Arguably, acts of an entity, even if formally done for a third party, that have the features of offering or marketing, are acts that infringe the trademark right. Such an entity, even acting on someone else's behalf, undertakes an act with features reserved for the benefit of the proprietor. It can, therefore, be concluded that the warehouse keeper ceases to be only a keeper but becomes, within the limits of his authorization, the possessor of the goods in the warehouse. Therefore, if that entity seeks to pursue the aim set by the entity placing the goods in storage we will be dealing with an infringement.

One should not lose sight of the fact that the concept of infringement of an exclusive right is based on unlawfulness. In practice, this means that examination of the existence of a specific form of infringement should boil down to an assessment of whether a materially specific act is identical with that reserved for the benefit of the proprietor. This leads to the conclusion that the person who materially carries

\footnotetext{
45 On joint liability for damage in relation to the English and American legal systems, Lievens (2011), p. 506; see also, regarding the German practice, Boos (2010), p. 427.

${ }^{46}$ For more in Polish writings on complicity and joint liability, see Machnikowski and Śmieja (2018), p. 458 et seq.
} 
out acts reserved for the benefit of the proprietor of the exclusive right cannot be treated as an intermediary, even when performing those acts on behalf of a third party. The requirement of personal pursuit of aims unnecessarily introduces an element of subjective evaluation of a given behaviour. It seems that the CJEU also noted that circumstance, indicating in paragraph 48 of the judgment that offering should be considered to be done by the warehouse keeper in a situation where no third-party sellers can be identified. ${ }^{47}$

Obviously, an argument that could be raised against such a classification of the acts of persons acting on someone else's behalf would theoretically be the lack of use of the sign in their market communications. The distinction between the use of a trademark and the creation of technical conditions for such use has been linked to the criterion of using the sign in one's own commercial communications, although this criterion will not always allow for that distinction to be made, as the Court itself admits. As indicated above, such an allegation could only apply to those forms of activity where a trademark may already be an instrument of communication. As the CJEU itself pointed out in the TOP Logistic ruling, the criterion of using a sign in one's own market communications does not have a universal value.

Therefore, the question remains whether the client who orders the activities formally corresponding to those reserved for the benefit of the proprietor is an infringer or only one inducing an infringement, i.e. an entity that will be held liable but only on the condition of fault.

Moving on to the assessment of the client's position, it is necessary to indicate at the outset that excluding his liability as the infringer, claiming the lack of use of the sign in commercial communications, would lead to an otherwise absurd conclusion that the client ordering those acts, remaining somewhat "hidden", would also not be the entity liable for the infringement. There is no doubt that the factual acts indicated in Art. 10(3) of Directive 2015/2436 do not exhaust the activities covered by the proprietor's exclusive right. The proprietor's exclusivity also includes consent to the use of the trademark by a third party. A question, therefore, arises whether an entity that consents to the use of a mark is also treated as the user of the mark. In my view, the use of a sign also includes the grant of a licence. Clearly, Directive 2015/2436 in Art. 16(6) provides that use of the trademark with the consent of the proprietor shall be deemed to constitute use by the proprietor. It does not matter for this assessment that the provision refers to real use. After all, it is, in a sense, a qualified form of using the mark. The licence, on the other hand, allows a third party to use the sign in the course of trade. The very grant of a licence is also an act reserved for the proprietor. Consenting to the use of a trademark by a third party is one of the attributes of protected exclusivity. Therefore, I believe that the entity that authorizes another entity to perform factual acts that constitute the exclusive sphere reserved for the benefit of the proprietor also directly infringes exclusive rights.

In the context of the CJEU judgment in the Coty case, there are obviously questions to what extent the resulting interpretation of stocking for the purpose of offering and placing on the market also remains valid for other industrial property

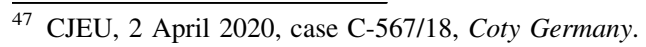


rights that do not fall under the category of distinctive rights. The use of an invention or a design in a situation of trade in goods containing protected intangible goods consists of using the properties of the intangible goods themselves. Their useful and aesthetic qualities determine their appeal. Answering the question about stocking, the CJEU made its answer independent of the criterion of using the sign in one's own commercial communications and linked it to the personal pursuit of aims which constitute factual acts reserved for the proprietor. Therefore, it seems that there are no construction arguments that would allow for a different perception of liability of the warehouse keeper. Also valid are the conclusions concerning those situations where in fact the warehouse keeper, acting for a third party, performs the act of offering or marketing, thus ceasing to be merely an entity creating technical conditions for use, and becoming an infringer.

\section{Conclusions}

Summing up, it should be said that the warehouse keeper, as long as he only provides a storage service, remains the entity creating technical conditions for use of the protected asset, allowing only its possession for the purpose of offering and marketing. This does not mean, however, that where other acts are performed at the request of the entity storing the goods, he also does not become the entity infringing industrial property rights.

In this context, it should also be noted that the example of stocking illustrates the difficulty of implementing EU law or international conventions into intellectual property law, especially in cases where the terms used are deeply rooted in private law institutions. It seems that the authors of these regulations do not always use the legal framework of concepts quite precisely. Remaining with the issues of stocking, it is worth mentioning Art. 8(1)(a) of Directive 2004/48, which allows asking for information from the entity that was "found to be in possession of infringing goods on a commercial scale". It seems that the intention of this provision was to be able to request information from the entity safekeeping the infringing goods. However, if we were to rely on the literal wording of this provision, such an entity would have to be excluded, since the power it exercises over the goods entrusted for safekeeping is not possession.

Finally, it should be pointed out that the tendency observed in the CJEU jurisprudence to restrict the interpretation of infringers and to treat them as entities that only create technical conditions for infringement is not always convincing. The Daimler and Coty cases seem to show a certain fear of the Court of applying liability for infringement to entities to which no fault can be attributed. This leads to a certain blurring of the interpretation of liability, based on unlawfulness and the absolute nature of exclusive rights. Creation of a category of intermediaries as entities that may also be held liable should not, in my view, lead to an excessive broadening of this category, encompassing entities which directly or indirectly carry out acts reserved for the proprietor. 
Open Access This article is licensed under a Creative Commons Attribution 4.0 International License, which permits use, sharing, adaptation, distribution and reproduction in any medium or format, as long as you give appropriate credit to the original author(s) and the source, provide a link to the Creative Commons licence, and indicate if changes were made. The images or other third party material in this article are included in the article's Creative Commons licence, unless indicated otherwise in a credit line to the material. If material is not included in the article's Creative Commons licence and your intended use is not permitted by statutory regulation or exceeds the permitted use, you will need to obtain permission directly from the copyright holder. To view a copy of this licence, visit http:// creativecommons.org/licenses/by/4.0/.

\section{References}

Boos S (2010) Carrier's liability for patent infringement under German law. IIC 2010(4):428-441 Haertel K (1986) Die Luxemburger Konferenz über das Gemeinschaftspatent 1985 und ihre wesentlichen Ergebnisse. GRUR Int 1986(5):293-301

Ingerl R, Rohnke C (2010) Markengesetz, 3rd edn. C.H. Beck, Munich

Krieger A (1988) The Luxembourg Convention on the Community Patent - a challenge and a duty. IIC 1988(2):143-157

Kur A, Senftleben M (2017) European trade mark law. A commentary. Oxford University Press, Oxford Lievens D (2011) eBay's accessory liability for counterfeiting - why joint tort liability just doesn't cut the mustard. IIC 2011(5):506-534

Machnikowski P, Śmieja A (2018). In: Olejniczak A (ed) System Prawa Prywatnego. C.H. Beck, Warsaw Pila J, Torremans P (2019) European intellectual property law. Oxford University Press, Oxford

Stauder D (1980) Comment on the judgment of the High Court of Justice, Patents Court 7 June 1979, British Airways. IIC 1980(4):513-515

Scharen U (2015) In: Benkard, Patentgesetz, 11th edn. C.H. Beck, Munich

Terrel T (2006) On the law of patents, 16th edn. Sweet \& Maxwell, London

Publisher's Note Springer Nature remains neutral with regard to jurisdictional claims in published maps and institutional affiliations. 